\title{
Edema and Nociception Induced by Philodryas patagoniensis Venom in Mice: A Pharmacological Evaluation with Implications for the Accident Treatment
}

\author{
Priscila Hess Lopes, Marisa M.T. Rocha, Alexandre Kazuo Kuniyoshi, \\ Fernanda Calheta Vieira Portaro, and Luís Roberto C. Gonçalves \\ Laboratório de Imunoquímica (P.H.L., A.K.K., F.C.V.P.), Laboratório de Herpetologia/Venenos (M.M.T.R.), and Laboratório de \\ Fisiopatologia (L.R.C.G.) Instituto Butantan, São Paulo-SP, Brazil
}

Received January 11, 2017; accepted March 23, 2017

\begin{abstract}
We have investigated the mechanisms involved in the genesis of edema and nociception induced by Philodryas patagoniensis venom $(\mathrm{PpV}$ ) injected into the footpad of mice. PpV induced dose-related edema and nociceptive effects. Pretreatment of mice with cyclooxygenase inhibitor (indomethacin), but not with cyclooxygenase 2 inhibitor (celecoxib) markedly inhibited both effects. Pretreatments with $\mathrm{H}_{1}$ receptor antagonist (promethazine) or with dual histamine-serotonin inhibitor (cyproheptadine) failed in inhibiting both effects. In groups pretreated with captopril (angiotensin-converting enzyme inhibitor) the edema was unaltered, but nociception was clearly increased, suggesting the
\end{abstract}

participation of kinins in the pathophysiology of the nociception but not of the edema-forming effect of PpV. When PpV was treated with EDTA, the nociception was similar to the one induced by untreated venom, but edema was markedly reduced. We concluded that PpV-induced edema and nociception have cyclooxygenase eicosanoids as the main mediators and no participation of vasoactive amines. Kinins seem to participate in nociception but not in edema induced by PpV. The results also suggest that metalloproteinases are the main compounds responsible for the edema, but not for the nociception induced by this venom.

\section{Introduction}

In Brazil, accidents induced by venomous snakes of the Viperidae and Elapidae families have significant human and veterinary importance. They are responsible for a high number of accidents in humans; however, from $20 \%$ to $40 \%$ of the snakebite cases are caused by the so-called nonvenomous snakes, which belong to the families Boidae and Colubridae (Salomão et al., 2003). The latter is the largest group of snakes with approximately 300 genera and 1850 species (Vidal, 2002). This group was recently divided into five new families, among which is the Dipsadidae family (Zaher et al., 2009).

Among the colubrid snakes belonging to the Dipsadidae family, the genus Philodryas is widespread in South America and is considered to be of medical interest. These snakes produce venom (Duvernoy's gland secretion) with sufficient toxicity to elicit serious lesions at the site of the bite. Although most accidents caused by these snakes do not result in serious consequences, some reports emphasize the importance of their toxins in causing local manifestations such as pain, edema, ecchymosis, hemorrhage, and in some cases necrosis, but no

This study was supported by Fundação de Amparo à Pesquisa do Estado de São Paulo [Grants 2006/52695-9, 2013/15344-7, and 2015/17053-5]. F.C.V.P. and L.R.C.G. are supported by research fellowships from the Conselho Nacional de Desenvolvimento Científico e Tecnológico.

The authors have no financial conflicts of interest.

https://doi.org/10.1124/jpet.116.239640. coagulation disturbances (Ribeiro et al., 1999; Prado-Franceschi and Hyslop, 2002; de Medeiros et al., 2010). Similarly, Philodryas patagoniensis venom $(\mathrm{PpV})$ causes local tissue damage as hemorrhage, edema, myonecrosis, and dermonecrosis, as well as pain (Acosta et al., 2003; Peichoto et al., 2004; Rocha and Furtado, 2007; de Medeiros et al., 2010).

The complexity of rear-fanged snake venom composition is reflected in the clinical symptoms of envenomation (Kuch and Mebs, 2002; Peichoto et al., 2012; Weinstein et al., 2013). Metalloproteinases play a critical role in the pathophysiology of colubrid envenomation since they are responsible for the hemorrhagic activity exhibited by many rear-fanged snake venoms (Peichoto et al., 2007; Weldon and Mackessy, 2012). Recent studies have described the purification and characterization of various components of colubrid venoms. Peichoto et al. $(2007,2009,2010)$ have isolated and characterized a metalloproteinase from $\mathrm{PpV}$. This toxin, named patagonfibrase, presents $\alpha$-fibrinolytic and hemorrhagic activities, and can induce hemorrhage and inflammation when injected in mice (Peichoto et al., 2011). These observations and proteomic studies (Weldon and Mackessy, 2010, 2012; Peichoto et al., 2012) have demonstrated that colubrid snake venoms have many proteins in common with the Viperidae venoms, and that severity of envenomation depends on the nature of the venom components (Peichoto et al., 2012).

Similarities between the pathophysiological manifestations of Bothrops spp. and $P$. patagoniensis may result in a misidentification

ABBREVIATIONS: MED, minimum edematogenic dose; PpV, Philodryas patagoniensis venom. 
of accidents by Philodryas as Bothrops envenomation (Cardoso and Fan, 1995; França and Málaque, 2003). In many instances, Bothrops antivenom was administered (Nishioka and Silveira, 1994; de Araújo and dos Santos, 1997; Ribeiro et al., 1999), potentially causing adverse effects (Nishioka and Silveira, 1994). Since edema and pain are the main local signs in accidents caused by Philodryas snakes, in some cases conservative treatments with antihistamine and anti-inflammatory drugs are employed (de Medeiros et al., 2010), but there is no information on the inflammatory mediators involved in these symptoms. Here, we studied the mechanisms involved in the genesis of the edema and the nociceptive effect induced by the venom of $P$. paragoniensis in mice.

\section{Material and Methods}

Philodryas Patagoniensis Venom. Venom from adult specimens of $P$. patagoniensis (90-120 cm body length) was obtained after a previous injection of pilocarpine $(10 \mathrm{mg} / \mathrm{kg})$ to induce secretion in Duvernoy's glands. The venom was collected with the aid of capillary tubes, lyophilized, and stored at $-20^{\circ} \mathrm{C}$ (Ferlan et al., 1983). The venom solutions were prepared with sterile physiologic saline $(0.15 \mathrm{M}$ $\mathrm{NaCl})$ at the moment of use, and the protein content was evaluated by the method employed in Markwell et al. (1978) using bovine serum albumin as the standard.

Animals. Male Swiss mice weighing 18-22 g, supplied by the Central Animal House of the Butantan Institute were used. Animals were maintained and used under strict ethical conditions according to the Brazilian Society of Laboratory Animal Science (SBCAL, http:// www.cobea.org.br). This study was submitted to the Institutional
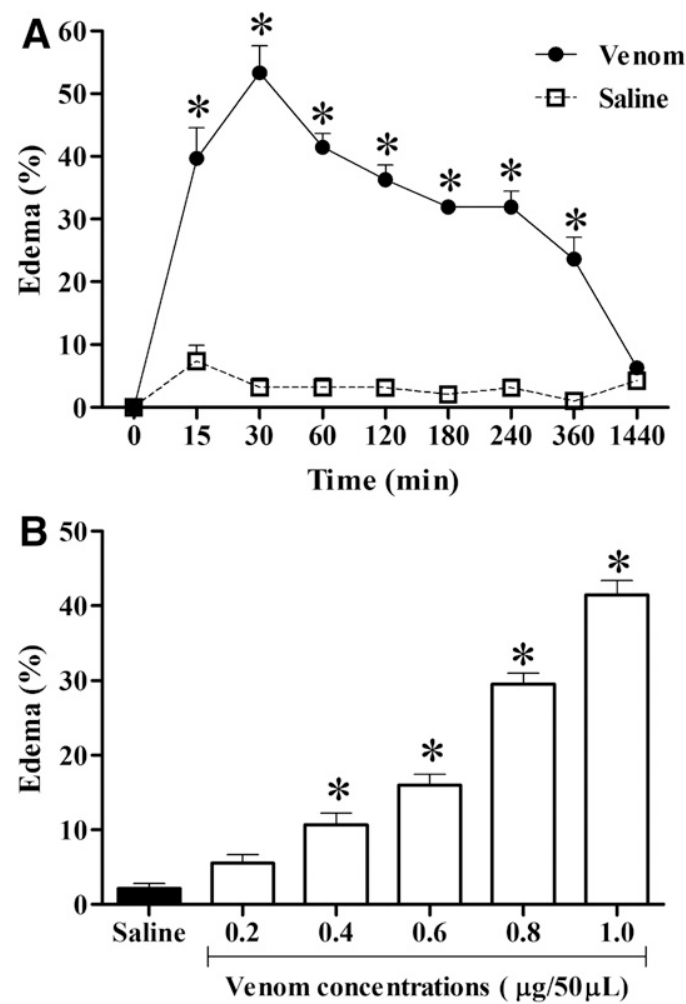

Fig. 1. Edema-forming activity of $\mathrm{PpV}$. Time course of edema induced by $1.0 \mu \mathrm{g} / 50 \mu \mathrm{l}$ of $\mathrm{PpV}$ in the footpad of mice (A) and effect of different doses of $\mathrm{PpV}$ on edema evaluated 30 minutes after injection (B). Edema (\%) is expressed as mean \pm S.E.M. of six animals, analyzed by one-way analysis of variance and Bonferroni post-test. (*) Statistically different from salineinduced edema.
Animal Care Committee at the Butantan Institute and was approved by protocol number 295/06.

Evaluation of Edema. The footpad of one of the hind paws of mice ( $n=6$ /group) was injected with $50 \mu \mathrm{l}$ of sterile saline solution $(0.15 \mathrm{M}$ $\mathrm{NaCl}$ ) containing different doses of $\mathrm{PpV}$, and the contralateral paw received the same volume of saline as the control. The paw volumes were evaluated with the aid of a plethysmometer (Panlab, Barcelona, Spain) at 15 and 30 minutes and 1, 2, 3, 4, 6, and 24 hours after the paw injections. The edema was expressed as the difference (\%) between the volumes of venom and saline-injected paws. The minimum edematogenic dose (MED) was defined as the venom dose able to induce $30 \%$ of paw increase (Yamakawa et al., 1976). In experiments of pharmacological modulation, the edema was evaluated only at 30 minutes after the injection of 2 MED of $\mathrm{PpV}$.

Evaluation of Nociception. Nociception was assessed after subcutaneous injection of $50 \mu \mathrm{l}$ of solutions containing saline or 0.5 , $1.0,3.0$, or $5.0 \mu \mathrm{g}$ of $\mathrm{PpV}$ into the footpad of the right hind paw of mice ( $n=9$ / group). The animals were placed in a glass chamber on a reflector surface for observation of nociceptive behavior. During 30 minutes of observation, we recorded the time (in seconds) that animals spent in nociceptive behavior (licking, shaking, or lifting the injected paw), as described in Hunskaar et al. (1985). In experiments of pharmacological modulation, the nociception was induced with 2.0 $\mu \mathrm{g}$ of $\mathrm{PpV}$.

Treatment of Animals. To evaluate the pharmacological modulation of edema and nociception, $\mathrm{PpV}$ was injected into a hind paw of nonblinded groups of 6-9 mice after the following pretreatments: (1) dexamethasone (corticosteroid, phospholipase $\mathrm{A}_{2}$ inhibitor; Hypofarma, Ribeirão das Neves, Brazil), $1 \mathrm{mg} / \mathrm{kg}$ i.p., 1 hour before; (2) indomethacin (cyclooxygenase inhibitor; Fluka Chemie AG, Buchs, Switzerland), $2 \mathrm{mg} / \mathrm{kg}$ s.c., 30 minutes before; (3) celecoxib (cyclooxygenase 2 inhibitor; Pfizer, Itapevi, Brazil), $5 \mathrm{mg} / \mathrm{kg}$ i.p., 30 minutes before; (4) promethazine $\left(\mathrm{H}_{1}\right.$ receptor antagonist; EMS Laboratories, Hortolândia, Brazil), 5 mg/kg i.p., 15 minutes before; (5) cyproheptadine (histamine and serotonin receptors antagonist; Sigma, São Paulo, Brazil), $2 \mathrm{mg} / \mathrm{kg}$ s.c., 30 minutes before; or (6) captopril (angiotensinconverting enzyme inhibitor; Medley, São Paulo, Brazil), 10 mg/kg i.p., 2 hours before. Control groups received only $\mathrm{PpV}$ into the paw.

Effect of EDTA on PpV-Induced Edema and Nociception. The effectiveness of EDTA treatment as a metalloprotease inhibitor was evaluated using a free resonance energy transfer peptide

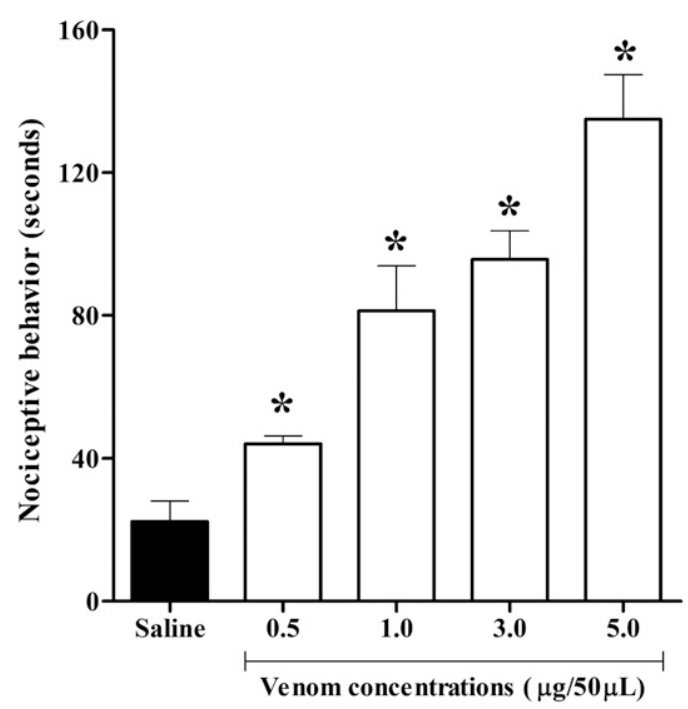

Fig. 2. Nociceptive effect of PpV. Effect of different doses of $\mathrm{PpV}$ in $50 \mu \mathrm{l}$ injected in the footpad of mice. Nociceptive behavior, represented as licking, shaking, or lifting time in seconds, is expressed as mean \pm S.E.M. of nine animals for each dose, analyzed by one-way analysis of variance and Bonferroni post-test. (*) Statistically different from saline-induced nociception. 
Abz-RPPGFSPFRQ-EDDnp as previously described in Kuniyoshi et al. (2012). Briefly, PpV activity assay was conducted in $7.4 \mathrm{pH}$ phosphate-buffered saline (final volume $100 \mu \mathrm{l}$ ) containing $50 \mathrm{mM}$ phosphate and $20 \mathrm{mM} \mathrm{NaCl}$, using Corning 96-well plates (Oakville, Canada) and a peptide substrate in a final concentration of $5 \mu \mathrm{M}$. The reactions occurred at $37^{\circ} \mathrm{C}$ and were initiated by the addition of $0.5 \mu \mathrm{g}$ of $\mathrm{PpV}$. There was an incubation period of 30 minutes at room temperature when phenylmethanesulfonylfluoride $(1 \mathrm{mM})$, 1,10-phenantroline ( $5 \mathrm{mM})$, and EDTA $(5 \mathrm{mM})$ where tested. When necessary, control samples were made in the presence of the same volume of ethanol used in the preparation of inhibitor stock solutions (phenylmethanesulfonylfluoride and 1,10-phenantroline). The experiments were made in triplicate.

Next, PpV venom was treated with $5 \mathrm{mM}$ of EDTA for 30 minutes at room temperature for the in vivo experimental procedure. EDTAtreated venom was injected into the hind paw of mice at doses used to evaluate edema or nociception as described previously. In the control groups crude venom or with the same concentration of EDTA was injected into the hind paws.

Statistical Analysis. The results are presented as mean \pm S.E. They were analyzed by one-way analysis of variance followed by Bonferroni test, or when appropriate by Student's $t$ test using the GraphPad Prism 5.01 software (GraphPad, San Diego, CA). Results were considered significant when $P<0.05$.

\section{Results}

Evaluation of Edema and Nociception Induced by PpV. PpV induced edema of rapid onset, which peaked 30 minutes after venom injection, decreased after that, and disappeared 24 hours after the experimental envenomation (Fig. 1A). The edematogenic activity was intense and dose dependent (Fig. 1B) and the MED was $0.82 \mu \mathrm{g}$. A dose of $1.64 \mu \mathrm{g}(2 \mathrm{MED})$ was used for the study of pharmacological modulation. This venom also induced dose-dependent nociception (Fig. 2). A dose of $2.0 \mu \mathrm{g}$ was used to study the pharmacological modulation.

Pharmacological Evaluation of PpV-Induced Edema and Nociception. The edema induced by $\mathrm{PpV}$ was significantly inhibited in groups pretreated with dexamethasone and indomethacin (Fig. 3). In contrast, nociception was

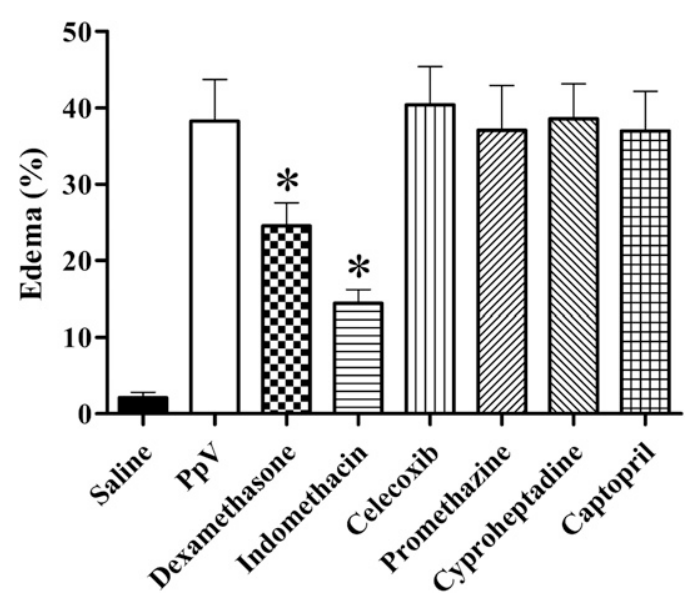

Fig. 3. Effect of the pretreatment with different drugs on paw edema induced by $\mathrm{PpV}$. The edema was evaluated 30 minutes after injection of $1.64 \mu \mathrm{g} / 50 \mu \mathrm{l}$ of $\mathrm{PpV}$ in the footpad of mice. Edema (\%) is expressed as mean \pm S.E.M. of six animals, analyzed by one-way analysis of variance and Bonferroni post-test. $\left.{ }^{*}\right)$ Results statistically lower $(P<0.05)$ than the control untreated PpV-injected group. significantly inhibited in the group pretreated with indomethacin. In the group treated with captopril the nociception was significantly increased (Fig. 4). In groups pretreated with celecoxib, promethazine, or cyproheptadine, edema and nociception were not affected (Figs. 3 and 4).

Effect of EDTA on PpV-Induced Edema and Nociception. Figure 5 shows that Abz-RPPGFSPFRQEDDnp hydrolysis was totally inhibited by both EDTA and 1,10-phenantroline, thus indicating complete inhibition of metalloproteinases present in the venom. This was unlike the results obtained with phenylmethanesulfonylfluoride, a serine protease inhibitor. Treatment of $\mathrm{PpV}$ with EDTA significantly inhibited its edema-forming activity (Fig. 6A) but did not affect the venom-induced nociception (Fig. 6B). Groups injected only with EDTA did not present significant edema or nociception (data not shown).

\section{Discussion}

In accidents caused by colubrid snakes, prominent edema and hyperalgesia is frequently present (Prado-Franceschi and Hyslop, 2002), as well as characteristic signs of acute inflammation. The venom of $P$. patagoniensis causes a rapid inflammatory response with marked edema and hyperalgesia. These local effects are intense, and are similar to the effects observed in Bothrops-induced envenomation, which can cause misinterpretation in the clinical diagnosis, despite the lack of blood coagulation disturbances (Puorto and França, 2003; de Medeiros et al., 2010).

Regarding the time course and intensity of the edematogenic response, our results are in agreement with studies that have shown a peak of activity 30 minutes after venom injection, with a dose-effect response (Rocha and Furtado, 2007). In fact, the edema induced by $\mathrm{PpV}$ reached the maximal intensity faster than in edema induced by some viperid

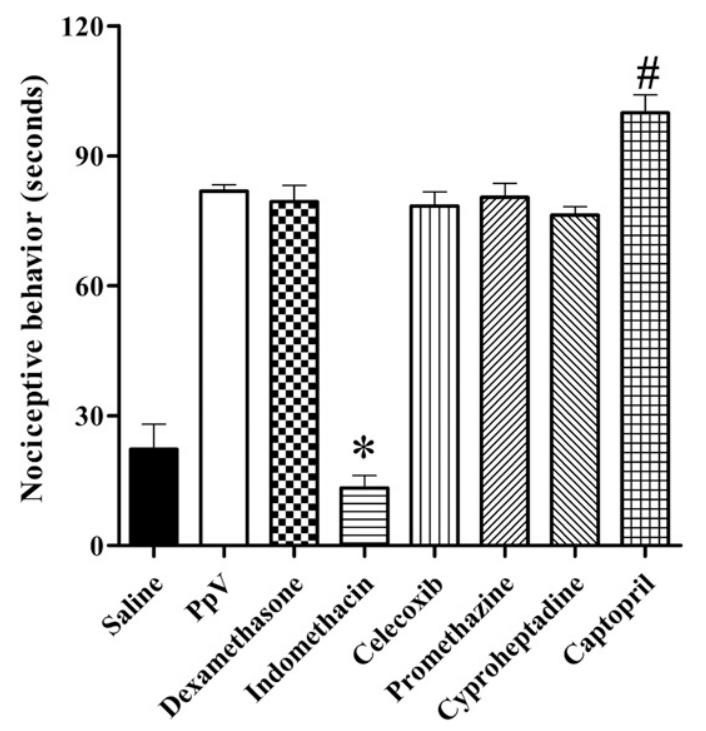

Fig. 4. Effect of the pretreatment with different drugs on the nociceptive behavior induced by $\mathrm{PpV}$. The nociceptive behavior induced by the injection of $2.0 \mu \mathrm{g} / 50 \mu \mathrm{l}$ of $\mathrm{PpV}$ is expressed as mean \pm S.E.M. of the licking time (seconds) of nine animals, analyzed by one-way analysis of variance and Bonferroni post-test. (*) Results statistically lower or (\#) results statistically higher $(P<0.05)$ than the control untreated PpVinjected group. 


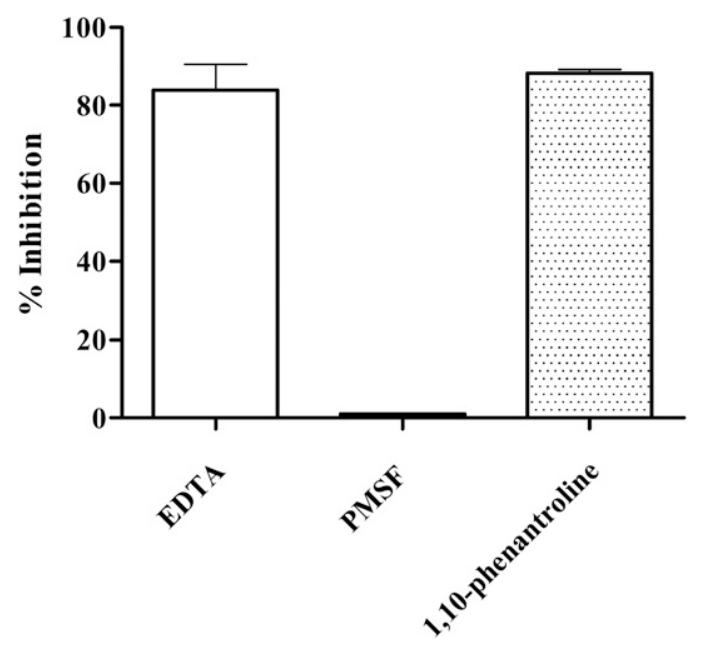

Fig. 5. Hydrolysis of the free resonance energy transfer substrate by $\mathrm{PpV}$ and the effect of classic inhibitors of metalloproteases and serine proteases. Inhibition effect of EDTA $(5 \mathrm{mM}), 1,10$-phenantroline $(5 \mathrm{mM})$, and phenylmethanesulfonylfluoride (PMSF) $(1 \mathrm{mM})$ upon the hydrolysis of Abz-RPPGFSPFRQ-EDDnp by Ppv $(0.5 \mu \mathrm{g})$. The results are expressed as mean \pm S.E.M. of triplicates.

venoms (Chaves et al., 1995; Gonçalves and Mariano, 2000; Barbosa et al., 2003; Al-Asmari and Abdo, 2006). We also found that $\mathrm{PpV}$ elicits a marked dose-dependent nociceptive response, which is more intense than that described in relation to $P$. olfersii venom (Rocha and Furtado, 2007).

Apart from case reports, epidemiologic studies, and studies on the characterization of the biologic activities of $\mathrm{PpV}$, to the best of our knowledge, this is the first experimental study on the pharmacological evaluation of inflammatory effects induced by this venom. Our results show that derivatives of arachidonic acid are the main mediators of edema induced by $\mathrm{PpV}$ since treatment with dexamethasone significantly inhibited this effect. The results of treatment with indomethacin and celecoxib indicate that eicosanoids from the cyclooxygenase pathway, but not from cyclooxygenase 2 , participate in this mediation. Arachidonic acid derivatives are the major players in the modulation of edema induced by some viperid snake venoms (Perales et al., 1992; Chaves et al., 1995; Gonçalves and Mariano, 2000; Barbosa et al., 2003)

In contrast, results obtained in groups treated with promethazine $\left(\mathrm{H}_{1}\right.$ receptor antagonist), cyproheptadine (histamine and serotonin inhibitor), or captopril (angiotensin-converting enzyme inhibitor) suggest that vasoactive amines and kinins do not play a role in the edema induced by $\mathrm{PpV}$. Other studies have shown that histamine does not participate in the edema induced by Bothrops jararaca or B. asper venom in mice (Perales et al., 1992; Chaves et al., 1995). However, this mediator can participate in the edema induced by other animal venoms, such as viperid venoms (Al-Asmari and Abdo, 2006; Galvão Nascimento et al., 2010; Sebia-Amrane and Laraba-Djebari, 2013), Lonomia caterpillar venom (de Castro Bastos et al., 2004), Potamotrygon motoro stingray venom (Kimura et al., 2015), and Echinometra lucunter sea urchin coelomic fluid (Sciani et al., 2014).

The nociceptive effect of $\mathrm{PpV}$ has a pharmacologic modulation distinct from the edema induced by this venom. Besides eicosanoids, the increase in nociceptive behavior after inhibition of the angiotensin-converting enzyme by captopril is
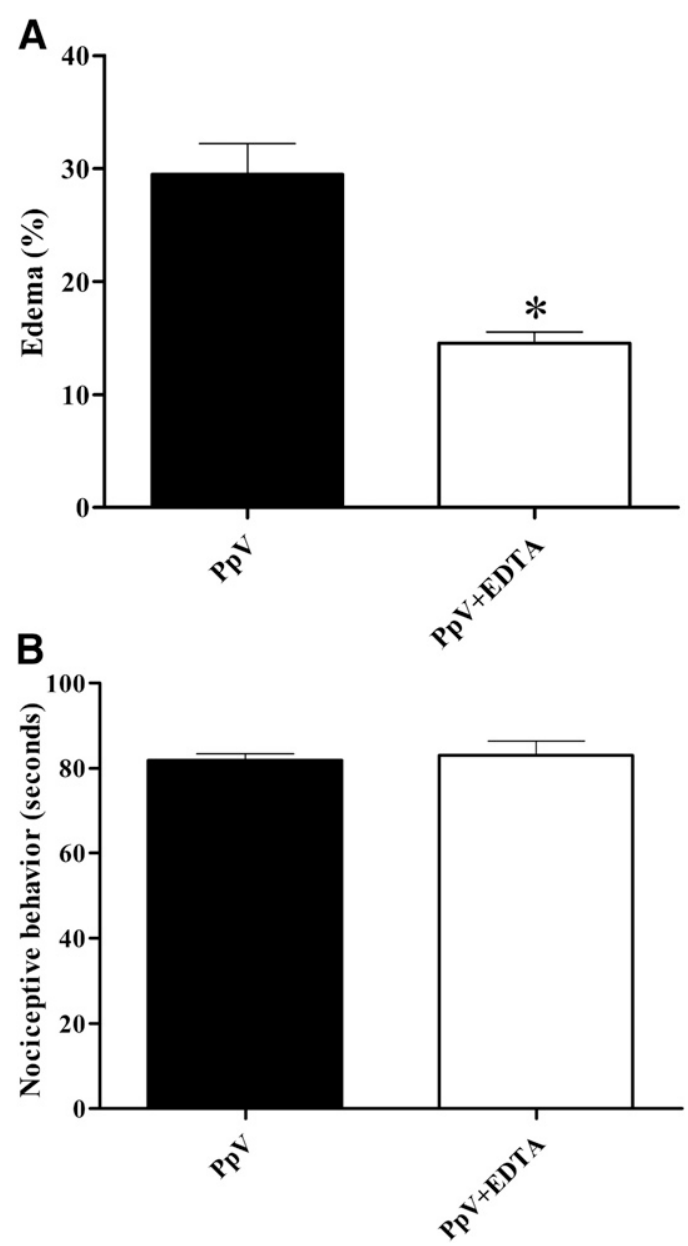

Fig. 6. Effect of treatment of $\mathrm{PpV}$ with EDTA on its edematogenic and nociceptive effect. Venom $(1.64$ and $2.0 \mu \mathrm{g} / 50 \mu \mathrm{l})$ treated with $5 \mathrm{mM}$ of EDTA was injected into the footpad of mice for evaluation of edema (A) and nociception (B). Results are expressed as mean \pm S.E.M., analyzed by Student's $t$ test. (*) Statistically different $(P<0.05)$.

indicative of kinins participation in the modulation of nociception induced by PpV. Bradykinin participates in nociception induced by some Bothrops venoms (Chacur et al., 2001, 2002), but not in the edema induced by these venoms (Trebien and Calixto, 1989; Chacur et al., 2001). Nevertheless, this mediator participates in edema and nociception induced by Thalassophryne nattereri fish venom (Lopes-Ferreira et al., 2004).

The inhibition of free resonance energy transfer substrate hydrolysis by EDTA corroborates that metalloproteinases have a central role in the edematogenic effect since a significant reduction in this effect in EDTA-treated $\mathrm{PpV}$ was found. This fact agrees with previous studies with an isolated toxin and with proteomic studies showing metalloproteinases as the main class of toxins present in PpV (Peichoto et al., 2011, 2012). In contrast, treatment with EDTA did not affect the nociceptive action of $\mathrm{PpV}$, suggesting the participation of other classes of toxins. It is well known that bradykinin is a major mediator of the pain induced by $B$. jararaca venom (Chacur et al., 2002) and that serine proteinases in this venom are the class of toxins responsible for the liberation of this nonapeptide (Serrano and Maroun, 2005; Serrano, 2013). Serine proteinases are present in colubrid venoms (Ching et al., 2006; 
Peichoto et al., 2012); however, until now there has been no information on kinin-releasing enzymes from colubrid venoms. This issue is under investigation by our group. In $B$. jararaca venom, metalloproteinases are the main compounds responsible for the inflammatory effect, and serine proteinases do not have consequences in its local inflammatory effect, despite having kininogenase activity (Zychar et al., 2010).

As cited previously, some accidents caused by Philodryas snakes have been wrongly diagnosed as Bothrops envenomation, resulting in the use of antivenom (de Medeiros et al., 2010). The use of Bothrops antivenom to treat cases of Philodryas envenomation do not have a clinical basis, despite the fact that some of the toxins of Philodryas venom are immunologically recognized by the Bothrops antivenom (Rocha et al., 2006). Since specific antivenoms are not available for treatment of colubrid-induced envenomation in Brazil, knowledge of the pharmacological mediation of the edema and pain induced by $\mathrm{PpV}$ can allow a therapeutic strategy. Clinical studies describe the use of antihistamine drugs as supportive treatment for this envenomation (de Medeiros et al., 2010); however, the present results indicate that histamine does not participate in the mediation of edema and nociception induced by $\mathrm{PpV}$. In contrast, our results suggest that treatment with cyclooxygenase inhibitors, such as indomethacin, may be beneficial in the treatment of edema and pain induced by $\mathrm{PpV}$, but further experimental and clinical studies need to be carried out to confirm this observation. Experimental studies have shown that in envenomationinduced by Bothrops spp., the use of anti-inflammatory drugs, such as dexamethasone, associated with serum therapy has a beneficial effect by reducing inflammatory edema more quickly and avoiding muscle damage (Araújo et al., 2007; Patrão-Neto et al., 2013). In conclusion, our results show that eicosanoids are the primary mediators of edema and nociception induced by $\mathrm{PpV}$, and suggest that nociception may also be mediated of kinins.

\section{Acknowledgments}

The authors thank Dr. Mônica Lopes-Ferreira for providing some drugs used in part of the experiments and especially Dr. Maria de Fátima D. Furtado for guidance and stimulus during this period.

\section{Authorship Contributions}

Participated in research design: Lopes, Rocha, Portaro, Gonçalves. Conducted experiments: Lopes, Rocha, Kuniyoshi.

Performed data analysis: Lopes, Portaro, Gonçalves.

Wrote or contributed to the writing of the manuscript: Lopes, Rocha, Kuniyoshi, Portaro, Gonçalves.

\section{References}

Acosta O, Leiva LC, Peichoto ME, Maruñak S, Teibler P, and Rey L (2003) Hemorrhagic activity of the Duvernoy's gland secretion of the xenodontine colubrid Philodryas patagoniensis from the north-east region of Argentina. Toxicon 41: 1007-1012.

Al-Asmari AK and Abdo NM (2006) Pharmacological characterization of rat paw edema induced by Cerastes gasperettii (Cerastes) venom. J Venom Anim Toxins Incl Trop Dis 12:400-417.

Araújo SD, de Souza A, Nunes FPB, and Gonçalves LRC (2007) Effect of dexamethasone associated with serum therapy on treatment of Bothrops jararaca venom-induced paw edema in mice. Inflamm Res 56:409-413.

Barbosa AM, do Amaral RO, Teixeira CFP, Hyslop S, and Cogo JC (2003) Pharmacological characterization of mouse hind paw oedema induced by Bothrops insularis (jararaca ilhoa) snake venom. Toxicon 42:515-523.

Cardoso JL and Fan HW (1995) Clinical toxicology of snake bites in South America, in Handbook of Toxicology of Animal Venoms and Poisons (Jürg M and White J eds) pp 667-688, CRC Press, Boca Raton, FL.

Chacur M, Picolo G, Gutiérrez JM, Teixeira CFP, and Cury Y (2001) Pharmacological modulation of hyperalgesia induced by Bothrops asper (terciopelo) snake venom. Toxicon 39:1173-1181.
Chacur M, Picolo G, Teixeira CFP, and Cury Y (2002) Bradykinin is involved in hyperalgesia induced by Bothrops jararaca venom. Toxicon 40:1047-1051.

Chaves F, Barboza M, and Gutiérrez JM (1995) Pharmacological study of edema induced by venom of the snake Bothrops asper (terciopelo) in mice. Toxicon 33: 31-39.

Ching ATC, Rocha MMT, Paes Leme AF, Pimenta DC, de Fátima D Furtado M, Serrano SMT, Ho PL, and Junqueira-de-Azevedo IL (2006) Some aspects of the venom proteome of the Colubridae snake Philodryas olfersii revealed from a Duvernoy's (venom) gland transcriptome. FEBS Lett 580:4417-4422.

de Araújo ME and dos Santos AC (1997) Cases of human envenoming caused by Philodryas olfersii and Philodryas patagoniensis (Serpentes: Colubridae). Rev Soc Bras Med Trop 30:517-519.

de Castro Bastos L, Veiga ABG, Guimarães JA, and Tonussi CR (2004) Nociceptive and edematogenic responses elicited by a crude bristle extract of Lonomia obliqua caterpillars. Toxicon 43:273-278.

de Medeiros CR, Hess PL, Nicoleti AF, Sueiro LR, Duarte MR, de Almeida-Santos SM, and França FOS (2010) Bites by the colubrid snake Philodryas patagoniensis: a clinical and epidemiological study of 297 cases. Toxicon 56:1018-1024

Ferlan I, Ferlan A, King T, and Russell FE (1983) Preliminary studies on the venom of the colubrid snake Rhabdophis subminatus (red-necked keelback). Toxicon 21: $570-574$

França FOS and Málaque CMS (2003) Acidente botrópico, in Animais peçonhentos no Brasil: biologia, clínica e terapêutica dos acidentes (Cardoso JLC, França FOS, Wen FH, Málaque CS, and Haddad, JrV eds) pp 72-86, Sarvier, São Paulo, Brazil.

Galvão Nascimento N, Sampaio MC, Amaral Olivo R, and Teixeira C (2010) Contribution of mast cells to the oedema induced by Bothrops moojeni snake venom and a pharmacological assessment of the inflammatory mediators involved. Toxicon 55:343-352.

Gonçalves LRC and Mariano M (2000) Local haemorrhage induced by Bothrops jararaca venom: relationship to neurogenic inflammation. Mediators Inflamm $\mathbf{9}$ 101-107.

Hunskaar S, Fasmer OB, and Hole K (1985) Formalin test in mice, a useful technique for evaluating mild analgesics. J Neurosci Methods 14:69-76.

Kimura LF, Prezotto-Neto JP Távora BCLF, Faquim-Mauro EL, Pereira NA Antoniazzi MM, Jared SGS, Teixeira CFP, Santoro ML, and Barbaro KC (2015) Mast cells and histamine play an important role in edema and leukocyte recruitment induced by Potamotrygon motoro stingray venom in mice. Toxicon 103: $65-73$.

Kuch U and Mebs D (2002) Envenomations by colubrid snakes in Africa, Europe, and the Middle East. J Toxicol Toxin Rev 21:159-179.

Kuniyoshi AK, Rocha M, Cajado Carvalho D, Juliano MA, Juliano Neto L, Tambourgi DV, and Portaro FCV (2012) Angiotensin-degrading serine peptidase: a new chymotrypsin-like activity in the venom of Bothrops jararaca partially blocked by the commercial antivenom. Toxicon 59:124-131.

Lopes-Ferreira M, Emim JA, Oliveira V, Puzer L, Cezari MH, Araújo MdaS, Juliano L, Lapa AJ, Souccar C, and Moura-da-Silva AM (2004) Kininogenase activity of Thalassophryne nattereri fish venom. Biochem Pharmacol 68:2151-2157.

Markwell MAK, Haas SM, Bieber LL, and Tolbert NE (1978) A modification of the Lowry procedure to simplify protein determination in membrane and lipoprotein samples. Anal Biochem 87:206-210.

Nishioka SA and Silveira PVP (1994) Philodryas patagoniensis bite and local envenoming. Rev Inst Med Trop Sao Paulo 36:279-281.

Patrão-Neto FC, Tomaz MA, Strauch MA, Monteiro-Machado M, Rocha JR, Jr, Borges PA, Calil-Elias S, and Melo PA (2013) Dexamethasone antagonizes the in vivo myotoxic and inflammatory effects of Bothrops venoms. Toxicon 69:55-64.

Peichoto ME, Acosta O, Leiva L, Teibler P, Maruñak S, and Ruíz R (2004) Muscle and skin necrotizing and edema-forming activities of Duvernoy's gland secretion of the xenodontine colubrid snake Philodryas patagoniensis from the north-east of Argentina. Toxicon 44:589-596.

Peichoto ME, Mackessy SP, Teibler P, Tavares FL, Burckhardt PL, Breno MC, Acosta O, and Santoro ML (2009) Purification and characterization of a cysteinerich secretory protein from Philodryas patagoniensis snake venom. Comp Biochem Physiol C Toxicol Pharmacol 150:79-84.

Peichoto ME, Paes Leme AF, Pauletti BA, Batista IC, Mackessy SP, Acosta O, and Santoro ML (2010) Autolysis at the disintegrin domain of patagonfibrase, a metalloproteinase from Philodryas patagoniensis (Patagonia Green Racer; Dipsadidae) venom. Biochim Biophys Acta 1804:1937-1942.

Peichoto ME, Tavares FL, Santoro ML, and Mackessy SP (2012) Venom proteomes of South and North American opisthoglyphous (Colubridae and Dipsadidae) snake species: a preliminary approach to understanding their biological roles. Comp Biochem Physiol Part D Genomics Proteomics 7:361-369.

Peichoto ME, Teibler P, Mackessy SP, Leiva L, Acosta O, Gonçalves LRC, TanakaAzevedo AM, and Santoro ML (2007) Purification and characterization of patagonfibrase, a metalloproteinase showing $\alpha$-fibrinogenolytic and hemorrhagic activities, from Philodryas patagoniensis snake venom. Biochim Biophys Acta 1770:810-819.

Peichoto ME, Zychar BC, Tavares FL, de Camargo Gonçalves LR, Acosta O, and Santoro ML (2011) Inflammatory effects of patagonfibrase, a metalloproteinase from Philodryas patagoniensis (Patagonia Green Racer; Dipsadidae) venom. Exp Biol Med (Maywood) 236:1166-1172.

Perales J, Amorim CZ, Rocha SLG, Domont GB, and Moussatché H (1992) Neutralization of the oedematogenic activity of Bothrops jararaca venom on the mouse paw by an antibothropic fraction isolated from opossum (Didelphis marsupialis) serum. Agents Actions 37:250-259.

Prado-Franceschi J and Hyslop S (2002) South American colubrid envenomations. $J$ Toxicol Toxin Rev 21:117-158.

Puorto G and França FOS (2003) Serpentes não peçonhentas e aspectos clínicos dos acidentes, in Animais peçonhentos no Brasil: biologia, clínica e terapêutica dos acidentes (Cardoso JLC, França FOS, Wen FH, Málaque CS, and Haddad, JrV eds) pp 108-114, Sarvier, São Paulo, Brazil. 
Ribeiro LA, Puorto G, and Jorge MT (1999) Bites by the colubrid snake Philodryas olfersii: a clinical and epidemiological study of 43 cases. Toxicon 37:943-948.

Rocha MM and Furtado MFD (2007) Analysis of biological activities from Philodryas olfersii (Lichtenstein) and P. patagoniensis (Girard) venoms (Serpents, Colubridae). Rev Bras Zool 24:410-418.

Rocha MMT, Paixão-Cavalcante D, Tambourgi DV, and Furtado MdeF (2006) Duvernoy's gland secretion of Philodryas olfersii and Philodryas patagoniensis (Colubridae): neutralization of local and systemic effects by commercial bothropic antivenom (Bothrops genus). Toxicon 47:95-103.

Salomão MG, Albolea ABP, and Almeida-Santos SM (2003) Colubroid snakebite: a public health problem in Brazil. Herpetol Rev 34:307-312.

Sciani JM, Sampaio MC, Zychar BC, Gonçalves LRC, Giorgi R, Nogueira TdeO, de Melo RL, Teixeira CdeF, and Pimenta DC (2014) Echinometrin: a novel mast cell degranulating peptide from the coelomic liquid of Echinometra lucunter sea urchin. Peptides 53:13-21.

Sebia-Amrane F and Laraba-Djebari F (2013) Pharmaco-modulations of induced edema and vascular permeability changes by Vipera lebetina venom: inflammatory mechanisms. Inflammation 36:434-443.

Serrano SMT (2013) The long road of research on snake venom serine proteinases. Toxicon 62:19-26.

Serrano SMT and Maroun RC (2005) Snake venom serine proteinases: sequence homology vs. substrate specificity, a paradox to be solved. Toxicon 45 1115-1132.

Trebien HA and Calixto JB (1989) Pharmacological evaluation of rat paw oedema induced by Bothrops jararaca venom. Agents Actions 26:292-300.

Vidal N (2002) Colubroid systematics: evidence for an early appearance of the venom apparatus followed by extensive evolutionary tinkering. J Toxicol Rev 21:21-41.
Weinstein SA, White J, Keyler DE, and Warrell DA (2013) Non-front-fanged colubroid snakes: a current evidence-based analysis of medical significance. Toxicon 69 : 103-113.

Weldon CL and Mackessy SP (2010) Biological and proteomic analysis of venom from the Puerto Rican Racer (Alsophis portoricensis: Dipsadidae). Toxicon 55:558-569.

Weldon CL and Mackessy SP (2012) Alsophinase, a new P-III metalloproteinase with $\alpha$-fibrinogenolytic and hemorrhagic activity from the venom of the rear-fanged Puerto Rican Racer Alsophis portoricensis (Serpentes: Dipsadidae). Biochimie 94: 1189-1198.

Yamakawa M, Nozaki M, Hokama Z, Ohsaka A, Hayashi K, and Sawai Y (1976) Fractionation of sakishima-habu (Trimeresurus elegans) venom and lethal, hemorrhagic, and edema-forming activities of the fractions, in Animal, plant and microbial toxins (Ohsaka A, Hayashi K, Sawaii Y, Murata R, Funatsu M, and Tamiya $\mathrm{N}$ eds) vol 1, pp 97-109, Plenum Press, New York.

Zaher H, Grazziotin FG, Cadle JE, Murphy RW, Moura-Leite JC, and Bonatto SL (2009) Molecular phylogeny of advanced snakes (Serpentes, Caenophidia) with an emphasis on South American Xenodontines: a revised classification and descriptions of new taxa. Pap Avulsos Zool 49:115-153.

Zychar BC, Dale CS, Demarchi DS, and Gonçalves LRC (2010) Contribution of metalloproteases, serine proteases and phospholipases $A_{2}$ to the inflammatory reaction induced by Bothrops jararaca crude venom in mice. Toxicon 55:227-234.

Address correspondence to: Dr. Priscila Hess Lopes, Laboratório de Imunoquímica, Instituto Butantan, Av. Vital Brazil, 1500, 05503-900, São Paulo-SP, Brazil. E-mail: priscila.lopes@butantan.gov.br 